\title{
SEASONAL VARIABILITY OF HISTORICAL AND PROJECTED FUTURE CLIMATE IN THE KATHMANDU VALLEY
}

\author{
Suraj Lamichhane ${ }^{1, *}$, Keshav Basnet ${ }^{2}$, Nirmal Prasad Baral'², Tek Bahadur Katuwal², and \\ Upendra Subedi ${ }^{3}$ \\ ${ }^{1}$ Institute of Engineering, Pulchowk Campus \\ ${ }^{2}$ Institute of Engineering, Pashchimanchal Campus \\ ${ }^{3}$ Institute of Engineering, Chitwan Campus \\ *E-mail:klsuraj@gmail.com
}

\begin{abstract}
Anthropogenic activities are the major drivers of climate change and the climatic variability is the major threat for the world development especially in Nepal. The Kathmandu Valley (KV) is the most urbanized capital city of Nepal that has sensed the climatic variation in terms of increase in temperature, precipitation, runoff, and flood for few decades. For the adaptation of climatic variability, historical and future climate change is depicted by the trend, seasonal, and yearly variation analysis using climate models based on observed data. Historically, minimum temperatures of the all seasons are in increasing and the seasonal average rate of precipitation in the KV watershed is declining. After analysis of the projected future climate using climate model (ACCESS-CSIRO-CCAM, CNRM-CM5 and CCSM4) with two representative concentration pathways (RCP) scenarios (i.e., RCP4.5 and RCP8.5), minimum and maximum temperature in the future (up to 2050) is increased by $0.66^{\circ} \mathrm{C}-0.6^{\circ} \mathrm{C}$ in RCP 4.5 and $1.21^{\circ} \mathrm{C}-1.04^{\circ} \mathrm{C}$ in RCP8.5 scenario. The rise in temperature means the warmer day will be increased and the erratic behavior of the precipitation will be expected in the future and the basin is expected to be drier in dry season and wetter in wet season. The analysis provides the alternative information for the planner for better planning, management, and adaptation strategy.
\end{abstract}

\section{Keywords}

Bagmati River basin, climate variability, Kathmandu valley, precipitation, temperature.

\section{Introduction}

Variation on the global climate and the energy imbalance is considered as the main indicator for the global warming and it is dramatically increased due to the increment of greenhouse gas concentration by the human activities such as industrializing, used of fossil fuel, Land
Use Land Cover (LULC) change, urbanization (Huang et al., 2011). The change in the global average temperature of $0.74{ }^{\circ} \mathrm{C} \pm 0.18{ }^{\circ} \mathrm{C}$ in the last 100 years (1906-2005) (IPCC, 2014) and the variation of the water cycle experienced due to the variation of the precipitation characteristics (Lamichhane and Shakya, 2019a) 
show examples of changing climatce dynamics. Many regions of the world have clearly experienced the significant climatic variability due to anthropogenic activity that created environmental, social and economic problems and the impacts would continue to appear in the future (Beskow et al., 2013). Especially, change in these two climate characteristics (temperature and precipitation) can easily alter the hydrological cycle and environmental processes. So, Climatic variability or climate changes are the major threats for the world development. Nepal has suffered the most as the country is least equipped to cope with climate change impacts (Mahmood et al., 2019)trends, and prediction for better water resource management and planning in a basin is very important. Since the water resources of the Lake Chad basin (LCB. In a developing country such as Nepal, where economy basically depends upon agriculture, substantial problems have occurred due to such variability (Pokhrel, 2018). Extreme precipitation either in terms of frequency, duration, and depth are the major causes of landslide, flood, and droughts. All these disasters in the country have caused tremendous losses in life and properties (Talchabhadel et al., 2018; Thapa et al., 2020)debris flows and all types of floods disasters in the country, which by causing tremendous losses of life and property affects the socio-economic development. Given the limited availability of knowledge in spatiotemporal distribution of precipitation in Nepal, this study analyses the spatial distribution of monthly and annual precipitation and 1-day extreme precipitation and their trends utilizing a large number of stations (291 stations for the first time.
The confidence of the climate model is basically judged by their physical basis, their skill in representing the generated climate data. All the climate change model has a limitation that leads to creating uncertainties at a different level (Randall et al., 2007). Future climate change projection is taken from the Global Climate Model (GCM), it basically depends upon the response of the global climate system to increase greenhouse gases for global warming and $\mathrm{CO}_{2}$ generation rate (IPCC, 2007). In the Himalayan region, the climatic variability has been very complex, downloaded and downscaled data of the climate have a higher degree of uncertainty. For the correct prediction, some bias correction has been applied after using the data (Shrestha et al., 2017).

The Kathmandu Valley (KV) is the most populated city that lies in the central Himalaya in Nepal and in the last three decades the urbanization pattern has been increased enormously (Rimal et al., 2017) and current population growth rate pattern of the Valley (Kathmandu, Lalitpur, and Bhaktapur) is three times greater than the national average rate (CBoS, 2014). The rise in the urban facilities, population growth, LULC change, and variation of water demand has triggered climate change in the future or now. The rises in temperature and precipitation characteristics are sensed in the KV these days. Different climatic models ACCESS-CSIRO-CCAM (Tamakoshi Basin, Songkhram River Basin in Thailand), CNRMCM5-CCAM (Tamakoshi Basin, Songkhram River Basin) (Aryal et al., 2017; Shrestha et al., 2018), CCSM4 (Tamakoshi Basin) (Aryal et al., 2019), CMIP5 (Indus Ganges and Brahmaputra River Basin, Kaligandaki Basin) (Bajracharya et al., 2018; Lutz et al., 2016), MPI-ESM-LR- 
CCAM (Kaligandaki, Tamakoshi, Songkhram River Basin) (Aryal et al., 2017; M. Shrestha et al., 2017; Shrestha et al., 2018), GFDL-CM3, MPI-ESM-LR, Nor ESM-M (Tamakoshi Basin) (Aryal et al., 2017), MRI-CGCM3 (Bagmati Basin) (Mishra and Herath, 2014), MRI-GCM, MIROC-ESM, HadGEM3-RA (Indrawati Basin) (Shrestha et al., 2016b) are used for the analysis of the climatic variability in the mountainous region of the Nepal like such as Kathmandu Valley. The climatic variation, topographical conditions and climate change scenarios are analyzed in different basins; meanwhile, Aryal et al. (2017) concluded that the Regional Circulation Models (RCMs) (ACCESSCSIRO-CCAM, CNRM-CM5, and CCSM4) generated from the respective GCMs are more reliable for the mountainous region. All of the aforementioned studies prevailed that the future climate change will be occurred either change in precipitation pattern or the variation of the minimum and maximum temperature of the basin.

Temperature and precipitation patterns alter due to climate change and it affects the river discharge, regional and local water availability and water supply (Shrestha et al., 2016). The Average temperature and precipitation will be increased due to climate change by $1.8^{\circ} \mathrm{C}$ $3.9^{\circ} \mathrm{C}$ and $1 \%$ to $12 \%$ respectively in Asia at the end of the century (IPCC, 2007). Many studies have been conducted in the world to recognize the effect of climate change in the water resources sector in the form of precipitation and temperature (Lutz et al., 2016; Mohammady et al., 2017; Sharma and Shakya, 2006; Thapa et al., 2017). The above studies have concluded that precipitation is occurring in greater extent in the wet season but declining in the dry season which causes the arid areas to be drier. The climate change study of the Hindu Kush Himalayan region (Indus, Ganges, and Brahmaputra river basins) highlights mean temperature has been rise up to $3.5^{\circ} \mathrm{C}$ and $6.3^{\circ} \mathrm{C}$ for $\mathrm{RCP} 4.5$, and RCP 8.5 (Lutz et al., 2016) and the precipitation shows higher level of uncertainty and the projection will be $3 \%$ to $37 \%$ in the RCP 4.5 and RCP 8.5. The historical climatic variation has been conducted in the Bagmati River basin that concludes the monsoon flood magnitude has a negative trend, but the duration and frequency have a positive trend (Sharma and Shakya, 2006). Similarly, the monsoon runoff is decreased, and other monsoon runoff is increased day by day. From the analysis of the Bagmati basin of Kathmandu Valley by using bias corrected GCM model, monsoon precipitation is depicted to rise and the other is less, which causes the flood magnitude to be increased in the future from 2\% to 40\% (Mishra and Herath, 2014). For the Indrawati Basin, the temperature has predicted to be increased by $2.5 \%$ to $4.9 \%$ of the end of the century that will eventually increase annual discharge of the basin (Shrestha et al., 2016). Representative Concentration Pathways Scenarios (RCP 4.5 and RCP 8.5) and hydrological model is used to simulate the climate change impact of the Kaligandaki river by Bajracharya et al. (2018), which predicts that the average annual temperature, precipitation, and discharge of the basin will be increased by $4^{\circ} \mathrm{C}, 26 \%$, and $50 \%$ respectively by the end of the 21st century under RCP 8.5 scenario. Anthropogenic actives in the urbanized area is the main key exciting factors for the climatic change and the consciences of the changing climatic variability in society are the main challenge for the researcher. The variation of climatic characteristics and its 
corresponding hydrological impact (Babel et al., 2014; Lamichhane and Shakya, 2019a; Mishra and Herath, 2014), recharge dynamics in the groundwater system ((Lamichhane and Shakya, 2019b) impact in groundwater aquifer (Lamichhane and Shakya, 2020) in the Kathmandu Valley has been assessed with the multiple objectives. But the future descriptive analysis is still lagged in the basin. Therefore, it is imperative to develop suitable set of future climatic scenarios and assess the impacts.

The perfect description, analysis, presentation, and findings of the historical climatic data (temperature and precipitation) trend and variability of the basin are very essential for the analysis of hydrology, energy generation, agriculture and other sectors. Both variabilities directly affect especially rain-fed irrigation system, surface-based water supply system, and runoff river-based hydropower projects, therefore the long term trend analysis in temperature and precipitation is mostly important with the future climatic scenario. The historical annual climate change trend, the seasonal variation of the temperature and precipitation are the initial objectives of the study. The RCMs climatic models and data outputs are generated through the concerning sources and biased correction is done after generation of the future climate. So, the main objectives of the study are set out to assess the variation of the climatic characteristics with respect to historical information and the different climatic models in the Kathmandu Valley.

\section{Materials and Methods}

\subsection{Study Area}

Kathmandu is the capital city of Nepal, which is situated in the central part of the country. The
Kathmandu Valley is a bowel shaped valley that covers the most parts of the Kathmandu, Lalitpur and Bhaktapur districts. The Bagmati River is the only one drainage network in the valley which originates from the range of Mahabharat hill of Shivapuri at an altitude of $2669 \mathrm{msl}$ as shown in Fig. 1. The study area is situated at the Latitude $27^{\circ} 37^{\prime} 44^{\prime \prime}$, Longitude $85^{\circ} 17^{\prime} 41^{\prime \prime}$ with the total catchment area 634 $\mathrm{km}^{2}$. The average yearly maximum, minimum and average temperature of the basin lies in between $24.2^{\circ} \mathrm{C}, 12.3^{\circ} \mathrm{C}$ and $18.2^{\circ} \mathrm{C}$ respectively. Similarly, the average annual rainfall depth of the basin is around $1535.4 \mathrm{~mm}$ from the analysis of 2000 to 2014 data (DHM, 2015). The valley climate varies from alpine in the northern part to sub-tropical in the riverbanks of the southern part. Basically, river basin precipitation is divided into three seasons pre-monsoon (January-May), monsoon (June- September), and post-monsoon (October-December) for the analysis. Average $10 \mathrm{~km}$ horizontal distances create the $1500 \mathrm{~m}$ level difference, so it has diversified climatic characteristics, topography and runoff pattern within the basin.

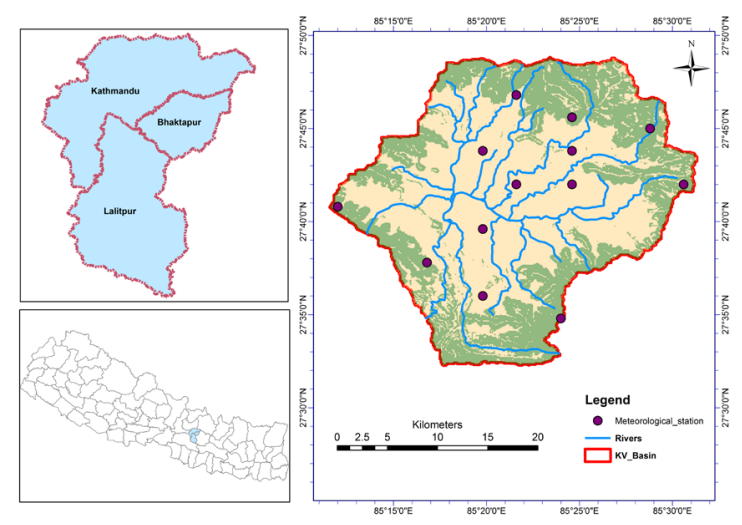

Figure 1: Location map of the study area

\subsection{Data}

For the analysis climatic (GCMs with RCMs 

data used for analysis is presented in Table 1. The overall methodological framework adopted for the study is shown in Fig. 2.

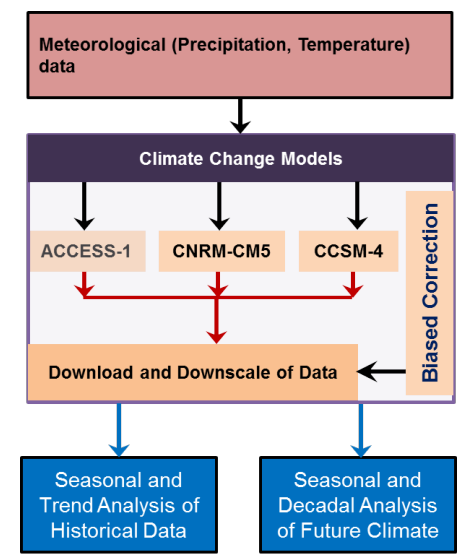

Figure 2: Methodological framework adopted for the study

\subsection{Climate models}

Various climate models have evolved over the features. The future climatic input value of each model has been generated by the General Circulation Models (GCMs) and Regional Climate Models (RCMs) with the different emission scenarios. Numerous techniques are available for downscaling and bias correction. The selection of the appropriate scenario, technique, and model for the climate change impact study is not straight forward (Lutz et al., 2016). The selection of the model depends upon historical climatic data sources, skills of a modeler, and the climatic variables of the model. The output of each model is varying due to the selection of model, data, downscaling, and biased correction techniques (Kharin et al., 2013). A list of the models considered for analysis is presented in Table 1. The GCMs simulate the three-dimensional physical properties of the climate by solving numerical conservation equations of mass, energy, momentum and water vapor including the equation of state.

decades and each model has its own computing

Table 1: Summary of data used for analysis

\begin{tabular}{|l|l|l|l|}
\hline Type of Data & Sources & Resolution & Length \\
\hline $\begin{array}{l}\text { Climate Change } \\
\text { (ACCESS- } \\
\text { CSIRO-CCAM) }\end{array}$ & $\begin{array}{l}\text { Collaboration for Australia Weather and } \\
\text { Climate Research, Australian Government }\end{array}$ & $\begin{array}{l}1.25 \times 1.40625 \\
\text { degree }\end{array}$ & $1975-2099$ \\
\hline $\begin{array}{l}\text { Climate Change } \\
\text { (CNRM-CM5) }\end{array}$ & $\begin{array}{l}\text { Centre National de Recherches } \\
\text { Me'te' orologiques (CNRM), France }\end{array}$ & $\begin{array}{l}1.4008 \times 1.875 \\
\text { degree }\end{array}$ & $1975-2099$ \\
\hline $\begin{array}{l}\text { Climate Change } \\
(\text { CCSM4) }\end{array}$ & $\begin{array}{l}\text { National Center for Atmospheric Research } \\
\text { (NCAR), USA }\end{array}$ & $\begin{array}{l}0.9424 \times 1.25 \\
\text { degree }\end{array}$ & $1975-2099$ \\
\hline Temperature & DHM (5 station) & Daily & 2000 to 2014 \\
\hline Precipitation & DHM (21 station) & Daily & 2000 to 2014 \\
\hline
\end{tabular}

\subsection{Climate scenarios}

Global or regional climate models project future climate based on various climatic scenarios that are defined based on population growth, economic development, LULC change, and atmospheric conditions. The IPCC assessment reports published in 2013 used a new set of scenarios, termed as RCP scenarios, which are 
defined based on theconcentration of greenhouse gases (GHG) in the atmosphere by the end of decades (IPCC, 2014). The concentration of GHG changes the solar radiation rate in Watts/ $\mathrm{m}^{2}$ in the earth atmosphere. Four RCP scenarios are defined, which are RCP2.6 (low emission), RCP4.5 (moderate emission), RCP6.5, and RCP8.5 (high emission). Shrestha et al. (2017b) used RCP scenarios to assess climate change impact in the water balance of Melamchi River based on climate data from a set of GCMs, and concluded that temperature and precipitation are projected to increase by $2.35^{\circ} \mathrm{C}$ and $4.25^{\circ} \mathrm{C}$, and $6 \%$ and $18 \%$ by the end of 2085 under RCP4.5 and RCP8.5 scenarios respectively. Most of the literatures showed that, in the context of Nepal, the medium and high RCP scenarios (RCP4.5 and RCP8.5) provide better information for future climate change analysis (Aryal et al., 2017; Babel et al., 2014; Bajracharya et al., 2018).

\subsection{Bias Correction}

The potential climate change impact in the study area was evaluated by the selected three GCM of the RCM (CCAM (ACCESS1.0), CCAM (CNRM-CM5) and CCAM (MPI-ESMLR)), these data have been quite reliable in the context of alpine and sub-tropical climate (Aryal et al., 2017). Daily precipitation and temperature (maximum and minimum) data of the region were downloaded and analyzed from 2000 to 2005 in RCP 4.5 and RCP 8.5. The entire climate model projected future climate data in the same location and the period (2006 to 2054) is used in the analysis. Daily and monthly average generated temperature and precipitation of RCMs were evaluated from the observed historical data.

\section{- $\quad$ Linear scaling}

Linear scaling technique is basically used to match the daily and monthly climate value into the observed value with certain correction. This method is similar to the constant scaling. It is applied to the mean value and corrects the generated value with the historically observed deviation of temperature and precipitation data. It is the easiest methods for the bias correction and it is also widely used (Aryal et al., 2017; Bajracharya et al., 2018; Shrestha et al., 2016).

\section{- Quantile mapping}

Quantile mapping is done by the empirical cumulative distribution function that includes both dry and wet days of the daily data. This method is derived from empirical transformation function (Themeßl et al., 2012) and effectively used in the precipitation and temperature simulated RCM for bias correction. In this research, the QM method was done in R language (Venables and Smith, 2013). It is successfully used in the different researches (Aryal et al., 2017; Mishra and Herath, 2014; Shrestha et al., 2018; Venables et al., 2018), and efficiently correct the bias for standard deviation, mean, and as well as wet and dry day frequency.

\subsection{Evaluation of bias correction}

In this study, the preference of the climatic model was evaluated based on widely used statistical parameters such as Nash-Sutcliffe simulation efficiency (NSE), percentage bias (PBIAS), coefficient of determination (R2), and the ratio of root mean square error (RMSE) to standard deviation ratio (RSR) (Santhi et al., 2001) before and after bias correction. All the bias-corrected data were compared with the observed data (2006 to 2014) for better evaluation. 
Nepal Engineers' Association, Gandaki 3. Results and Discussion

\subsection{Trends and variabilities in historical climate}

The climate of KV is mostly semi-tropical and the monthly average maximum and minimum temperatures vary from $29.8^{\circ} \mathrm{C}$ to $3.4^{\circ} \mathrm{C}$ and the average humidity of the basin is $75 \%$ (DHM, 2015). The weather of the KV is mainly categorized into three periods: 1) pre-monsoon (Mar-May), 2) summer monsoon (Jun-Sep), and 3) post-monsoon (Oct-Feb). The average mean monthly precipitation ranges from 4.2 $\mathrm{mm}$ in December to $402.1 \mathrm{~mm}$ in July and average annual rainfall is $1,533 \mathrm{~mm} / \mathrm{yr}$. There is strong seasonality in the rainfall, with more than $80 \%$ of the annual rainfall is received during the monsoon period (June -September). The observed minimum and maximum temperature data at the Khumaltar station (St. No. 1029) showed that minimum temperature of all seasons is in increasing trend, thus indicating prospects for the warmer future and subsequent increase in evaporation from the basin. Similarly, the maximum temperature has rising trend in the monsoon season but decreasing in the pre-monsoon and postmonsoon seasons (Fig. 3).

The seasonal (Pre-monsoon, Monsoon, and Post-monsoon) average rate of precipitation in the KV watershed is declining and it reduces the water balance in the valley as per Fig. 4. In almost all seasons, the variation of the precipitation was observed to be declining.

From the analysis of the available observed data of the Kathmandu valley various meteorological station, The Mann-Kendall test performed that the observed value provides the seasonal as well as annual variation in the data in Table 2.

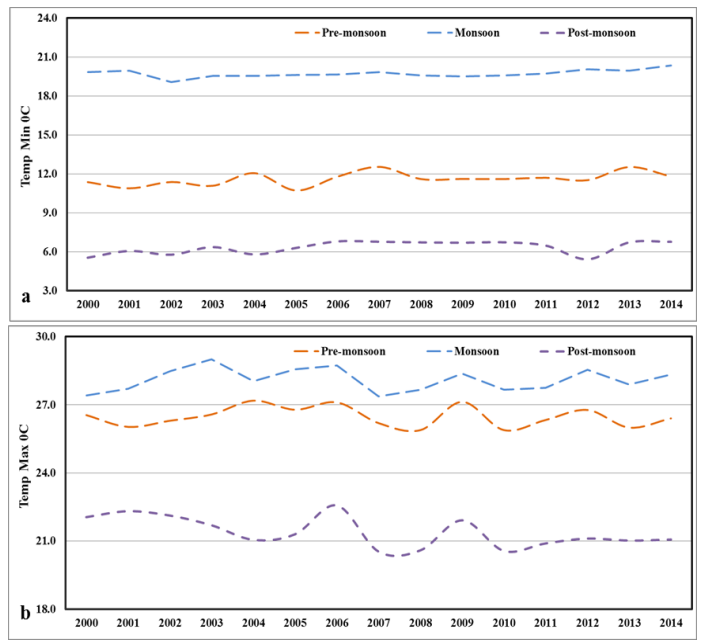

Figure 3: Average annual and seasonal observed temperature: a) Minimum temperature and b) Maximum temperature

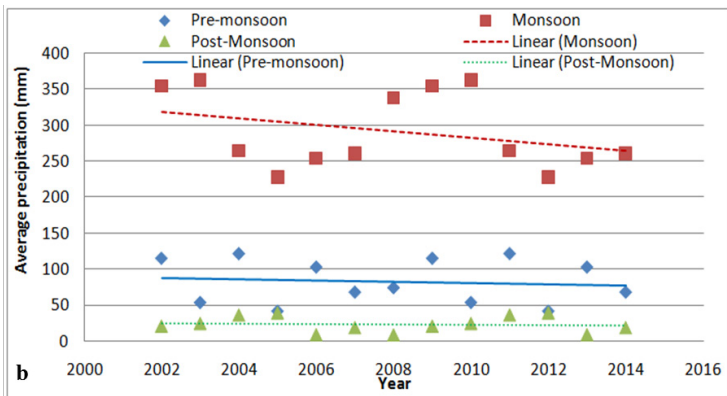

Figure 4: Seasonal precipitation patterns

From the analysis clearly indicate that the annual, pre-monsoon, monsoon precipitation within the basin is decreased but the post monsoon season is increasing trend that indicate the basin runoff and the hydrograph shape and characteristics will be change due to seasonal precipitation variation. The pre-monsoon season trend of the basin will be towards the dry due to rise in temperature and reduce the precipitation depth. 
Table 2: Summary of Mann-Kendall's analysis

\begin{tabular}{|l|l|l|l|l|l|}
\hline Parameters & Seasons & Z-Value & Kendall-Tau & Sen's slope & p-value \\
\hline \multirow{4}{*}{$\mathrm{T}_{\max }$} & Pre-monsoon & -0.35 & -0.08 & -0.01 & 0.73 \\
\cline { 2 - 6 } & Monsoon & 1.83 & 0.36 & 0.04 & 0.07 \\
\cline { 2 - 6 } & Post-monsoon & -1.78 & -0.35 & -0.09 & 0.07 \\
\hline \multirow{5}{*}{$\mathrm{T}_{\min }$} & Pre-monsoon & 1.83 & 0.36 & 0.04 & 0.07 \\
\cline { 2 - 6 } & Monsoon & 1.64 & 0.32 & 0.03 & 0.1 \\
\cline { 2 - 6 } & Post-monsoon & 1.78 & 0.35 & 0.06 & 0.07 \\
\hline \multirow{5}{*}{$\mathrm{T}_{\text {average }}$} & Pre-monsoon & 0.55 & 0.11 & 0.02 & 0.59 \\
\cline { 2 - 6 } & Monsoon & 0.94 & 0.19 & 0.01 & 0.35 \\
\cline { 2 - 6 } & Post-monsoon & -0.79 & -0.16 & -0.02 & 0.43 \\
\cline { 2 - 6 } & T annual & 0.19 & 0.18 & 0.01 & 0.37 \\
\hline \multirow{5}{*}{ PPT $_{\text {all }}$} & Pre-monsoon & -1.58 & -0.31 & -2.28 & 0.11 \\
\cline { 2 - 6 } & Monsoon & -0.99 & -0.2 & -4.56 & 0.32 \\
\cline { 2 - 6 } & Post-monsoon & 1.19 & 0.24 & 0.62 & 0.23 \\
\cline { 2 - 6 } & P annual & -0.31 & -0.30 & -2.07 & 0.14 \\
\hline
\end{tabular}

3.2 Trends and variabilities in projected future climate

Two emission scenarios viz. RCP4.5 (medium) and RCP8.5 (high) were used for the analysis of the future climate. The temperature and precipitation data were generated by using three RCMs (ACCESS-CSIRO-CCAM, CNRMCM5-CSIRO-CCAM, and CCSM-4). Aryal et al. (2017) suggest that in alpine and sub-tropical climate, these data are quite reliable. The daily maximum and minimum precipitation and temperature data of the study area were downloaded from South Asia Cordex for the period of 2000 to 2005 under RCP4.5 and RCP8.5 scenarios and analyzed. To remove the uncertainty of the climate model generated data, bias correction was done by using the linear scaling method and quantile mapping.

All the bias-corrected data were compared with the observed data (2006 to 2014) for better evaluation. From the observation, the climatic model gave the overestimation for precipitation and the underestimation for temperature to compare the observed data. For three RCMs, two RCPs, and two bias correction techniques, 12 scenarios were created. Overall comparison of the all climate model data with the observed data of the study area, the generated data from the ACCESS-1 model was more reliable than the other models. All the statistical parameters (NSE, $\mathrm{R}^{2}$, and PBIAS) of the model were more significant than the others. Similarly, for the bias correction, the statistical indicator performance of the quantile mapping was better than the linear scaling. Another study has also highlighted that ACCESS-1 with quantile mapping bias correction has robust preference for climate and topographical regions (Aryal et al., 2017; Babel et al., 2014; Bajracharya et al., 2018; Mishra et al., 2018). Precipitation and temperature ( $\max , \min$ ) of the study area were generated by the three RCMs for the analysis under RCP4.5 (medium) and RCP8.5 (high) scenarios for up to 2055. All the generated data was divided in two decadal intervals for the 

in RCP4.5 and by $1 \%$ in RCP8.5 respectively when using quantile mapping bias correction. Similarly, the average annual $\mathrm{T}_{\max }$ and $\mathrm{T}_{\text {min }}$ will be increased by $0.19^{\circ} \mathrm{C}$ and $0.33^{\circ} \mathrm{C}$ in RCP4.5 and $0.89^{\circ} \mathrm{C}$ and $0.96^{\circ} \mathrm{C}$ in $\mathrm{RCP} 8.5$ respectively (Fig. 5). The bias corrected data were compared with the baseline data to estimate absolute changes in precipitation and temperature. Two scenarios were considered for 2030s and 2050s. The RCM-based baseline (after bias correction) was used rather than observed one to make sure the differences are more realistic.

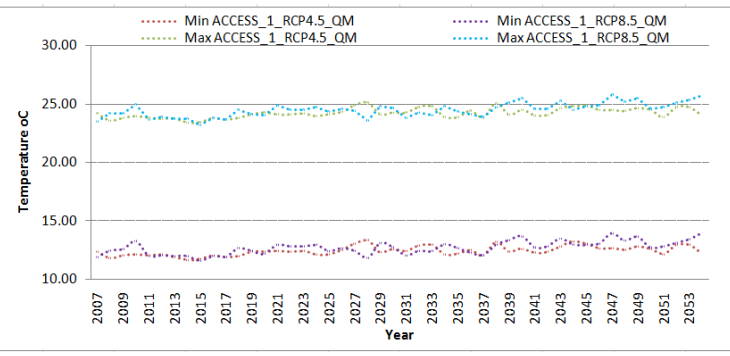

Figure 5: Future generated $\mathrm{T}_{\text {max }}$ and $\mathrm{T}_{\text {min }}$ by both RCPs

Both scenarios show that average annual values of both the minimum and maximum temperatures increase consistently for all future scenarios considered in this study. The absolute changes in average annual maximum temperature are 0.70 and $0.66^{\circ} \mathrm{C}$ under RCP4.5 and 0.32 and $1.21^{\circ} \mathrm{C}$ under RCP8.5 for 2030s, and 2050s respectively (Table 3). Similarly, absolute changes in average annual minimum temperature are 0.65 and $0.60^{\circ} \mathrm{C}$ under RCP4.5 and 0.24 and $1.04^{\circ} \mathrm{C}$ under RCP8.5 during the two decadal future series respectively. It is evident that rate of increase in maximum temperature is more than the minimum temperature for both the RCP scenarios. The rate of increase is higher under RCP8.5 scenarios when compared in temperature, both maximum and minimum, the rate of increase varies across the seasons. The rate of increase in maximum temperature during post-monsoon season is considerably higher compared to other seasons as well as annual. The minimum temperature also follows similar trend. Similar results are reported in other literature related to Nepal and South Asia as well (see e.g. Bajracharya et al., 2018; Guo-yu and Bhakta, 2017; Mishra and Herath, 2014; M. Shrestha et al., 2017).

In the case of precipitation, average annual precipitation in general shows an increasing trend for all the scenarios and future periods considered, except for 2050s under RCP8.5. For example, it increases by, $7 \%$ and $21 \%$ for 2030s and 2050s under RCP4.5 scenarios. The percentage change, however, varies across the seasons. In general, precipitation is projected to increase in monsoon seasons, under RCP4.5 scenarios with the rate higher than the average annual values. In the case of post-monsoon, precipitation is projected to decrease in the first two decades and then increase. However, there is no consistent trend in precipitation, which is also reported in other literatures (Aryal et al., 2017; Babel et al., 2014; Bajracharya et al., 2018; Karki et al., 2017; Lutz et al., 2016; Mishra et al., 2018). In 2030, the rate of precipitation has the decreasing trend (-11\%); however, the both max. and min. temperatures are increasing $\left(+0.91\right.$ and $\left.+0.92^{\circ} \mathrm{C}\right)$, which shows that 2030 would be drier than the other decades. For both RCP scenarios, the rate of increase in minimum temperature was greater than the maximum temperature. 
Table 3: Projected changes in precipitation and temperature with respect to baseline (2010)

\begin{tabular}{|c|c|c|c|c|c|c|c|c|c|}
\hline \multirow{2}{*}{\multicolumn{2}{|c|}{$\begin{array}{c}\text { Decade } \\
\text { Pre-monsoon }\end{array}$}} & \multicolumn{4}{|c|}{ RCP 4.5} & \multicolumn{4}{|c|}{ RCP 8.5} \\
\hline & & \multirow{2}{*}{\begin{tabular}{|c|} 
Monsoon \\
229
\end{tabular}} & \multirow{2}{*}{\begin{tabular}{|c|}
$\begin{array}{c}\text { Post- } \\
\text { monsoon }\end{array}$ \\
1,127 \\
\end{tabular}} & \multirow{2}{*}{\begin{tabular}{|c|} 
Annual \\
160
\end{tabular}} & \multirow{2}{*}{$\begin{array}{c}\begin{array}{c}\text { Pre- } \\
\text { monsoon }\end{array} \\
1,516\end{array}$} & \multirow{2}{*}{\begin{tabular}{|c|} 
Monsoon \\
264 \\
\end{tabular}} & \multirow{2}{*}{$\begin{array}{c}\begin{array}{c}\text { Post- } \\
\text { monsoon }\end{array} \\
1,251\end{array}$} & \multirow{2}{*}{$\begin{array}{c}\text { Annual } \\
139 \\
\end{array}$} & \multirow[b]{2}{*}{1,654} \\
\hline$\cong$ & Baseline ${ }^{*}$ & & & & & & & & \\
\hline$\overbrace{0}^{\infty} \overbrace{}^{\circ}$ & 2030 & -11 & 13 & -8 & 7 & 5 & -2 & 41 & 3 \\
\hline & 2050 & 32 & 13 & 66 & 21 & 29 & -19 & 24 & -8 \\
\hline \multirow{3}{*}{ 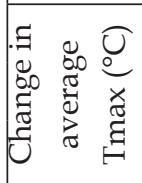 } & Baseline $^{\$}$ & 25.10 & 27.20 & 20.25 & 24.18 & 25.22 & 27.17 & 20.72 & 24.37 \\
\hline & 2030 & 0.91 & 0.51 & 0.67 & 0.70 & 0.14 & 0.56 & 0.26 & 0.32 \\
\hline & 2050 & 0.45 & 0.66 & 0.87 & 0.66 & 1.33 & 1.44 & 0.85 & 1.21 \\
\hline \multirow{3}{*}{ 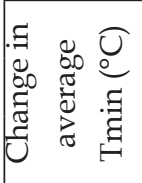 } & Baseline $^{\$}$ & 11.40 & 18.89 & 6.85 & 12.38 & 11.40 & 18.89 & 7.50 & 12.6 \\
\hline & 2030 & 0.92 & 0.27 & 0.77 & 0.65 & 0.16 & 0.34 & 0.21 & 0.24 \\
\hline & 2050 & 0.42 & 0.42 & 0.97 & 0.60 & 1.29 & 0.90 & 0.94 & 1.04 \\
\hline
\end{tabular}

\section{Conclusion}

The study projected the future climate (temperature and precipitation) based on three regional climate models (RCMs) (ACCESSCSIRO-CCAM, CNRM-CM5 and CCSM4), and two representative concentration pathways (RCP) scenarios (RCP4.5 and RCP8.5). Linear scaling and quantile mapping techniques were used for bias correction of the RCM data. The performance of the ACCESS-1, biascorrected with quantile mapping method, gave a convincing output when compared with the observed data, and therefore, the same was used for further evaluation of climate change impacts. Following conclusions can be drawn from the study:

- The historical observed data indicates that the annual precipitation was decreasing and average temperature was increasing trend. Similarly, pre-monsoon and monsoon the rise temperature and fall precipitation creates the basin dryer and vice versa in post-monsoon seasons.

- In general, the minimum, maximum temperature, and precipitation in future (upto 2050) from both scenarios is projected to increase by $0.66^{\circ} \mathrm{C}-0.6^{\circ} \mathrm{C}$ and $+21 \%$ in RCP 4.5 , and $1.21^{\circ} \mathrm{C}-1.04^{\circ} \mathrm{C}$ and $-8 \%$ in RCP8.5 scenarios. The rate of increase in $\mathrm{T}_{\max }$ is greater than the $\mathrm{T}_{\min }$ in both scenarios. The projected change in precipitation can be considered more erratic in the RCP 8.5 compare the RCP4.5. In summary, summer would be extended in the KV and the temperature of winter would be decreased further in the future. As per the seasonal comparison, the rate of increase in winter maximum and minimum temperature is greater than the summer seasons that means the warmer day will be increased in the future. Such projected variation of climatic characteristics is more useful for the future planning and adaptation strategy of the basin.

\section{References}

Aryal, A., Shrestha, S., Babel, M.S., 2017. Quantifying the sources of uncertainty in an ensemble of hydrological climate- 
impact projections. Theor. Appl. Climatol. 135, 193-209.

Babel, M.S., Bhusal, S.P., Wahid, S.M., Agarwal, A., 2014. Climate change and water resources in the Bagmati River Basin, Nepal. Theor. Appl. Climatol. 115, 639-654. https://doi.org/10.1007/s00704013-0910-4

Bajracharya, A.R., Bajracharya, S.R., Shrestha, A.B., Maharjan, S.B., 2018. Climate change impact assessment on the hydrological regime of the Kaligandaki Basin, Nepal. Sci. Total Environ. 625, 837-848.

Beskow, S., Norton, L.D., Mello, C.R., 2013. Hydrological prediction in a tropical watershed dominated by oxisols using a distributed hydrological model. Water Resour. Manag. 27, 341-363.

CBoS, 2014. Population Atlas of Nepal.

DHM, 2015. Hydrological records of Nepal, streamflow summary, updated version. Department of Hydrology and Meteorology: Goverment of Nepal, Ministry of Water Resources, Kathmandu.

Guo-yu, R.E.N., Bhakta, A., 2017. Climate change in the Hindu Kush Himalaya ScienceDirect Climate change in the Hindu Kush Himalaya. Adv. Clim. Chang. Res. https://doi.org/10.1016/j. accre.2017.09.001

Huang, J., Zhang, J., Zhang, Z., Xu, C.Y., Wang, B., Yao, J., 2011. Estimation of future precipitation change in the Yangtze River basin by using statistical downscaling method. Stoch. Environ. Res. Risk Assess. 25, 781-792. https://doi.org/10.1007/ s00477-010-0441-9

IPCC, 2014. Climate Change 2014: Synthesis Report. Contribution of Working Groups I, II and III to the Fifth Assessment
Report of the Intergovernmental Panel on Climate Change [Core Writing Team, R.K. Pachauri and L.A. Meyer (eds.)], IPCC, Geneva, Switzerland. https://doi. org/10.1177/0002716295541001010

IPCC, 2007. Intergovernmental Panel on Climate Change, "Summary for policymakers, climate change 2007: The physical science basis." Contribution of Working Group I to the Fourth Assessment Rep. of the Intergovernmental Panel on Climate Change . Cambridge University Press, Cambridge, U.K.

Karki, R., Hasson, S., Schickhoff, U., Scholten, T., 2017. Rising Precipitation Extremes across Nepal 1-25. https://doi. org/10.3390/cli5010004

Kharin, V. V., Zwiers, F.W., Zhang, X., Wehner, M., 2013. Changes in temperature and precipitation extremes in the CMIP5 ensemble. Clim. Change 119, 345-357. https:// doi.org/10.1007/s10584-0130705-8

Lamichhane, S., Shakya, N.M., 2020. Journal of Hydrology: Regional Studies Shallow aquifer groundwater dynamics due to land use / cover change in highly urbanized basin : The case of Kathmandu Valley. J. Hydrol. Reg. Stud. 30, 100707. https:// doi.org/10.1016/j.ejrh.2020.100707

Lamichhane, S., Shakya, N.M., 2019a. Integrated Assessment of Climate Change and Land Use Change Impacts on Hydrology in the Kathmandu Valley Watershed, Central Nepal. Water (Switzerland) 11, 1-17. https://doi. org/10.3390/w11102059

Lamichhane, S., Shakya, N.M., $2019 b$. Alteration of groundwater recharge areas due to land use/cover change in 
Kathmandu Valley, Nepal. J. Hydrol.

Reg. Stud. 26, 100635. https://doi. org/10.1016/j.ejrh.2019.100635

Lutz, A.F., ter Maat, H.W., Biemans, H., Shrestha, A.B., Wester, P., Immerzeel, W.W., 2016. Selecting representative climate models for climate change impact studies: an advanced envelope $\square$ based selection approach. Int. J. Climatol. 36, 3988-4005.

Mahmood, R., Jia, S., Zhu, W., 2019. Analysis of climate variability, trends, and prediction in the most active parts of the Lake Chad basin, Africa. Sci. Rep. 9, 1-18. https:// doi.org/10.1038/s41598-019-42811-9

Mishra, B.K., Herath, S., 2014. Assessment of future floods in the Bagmati River Basin of Nepal using bias-corrected daily GCM precipitation data. J. Hydrol. Eng. 20, 5014027.

Mishra, Y., Nakamura, T., Babel, M.S., Ninsawat, S., Ochi, S., 2018. Impact of climate change on water resources of the Bheri River Basin, Nepal. Water (Switzerland) 10, 1-21. https://doi. org/10.3390/w10020220

Mohammady, M., Moradi, H.R., Zeinivand, H., Temme, A., Yazdani, M.R., Pourghasemi, H.R. \%J T., climatology, applied, 2017. Modeling and assessing the effects of land use changes on runoff generation with the CLUE-s and WetSpa models 1-13.

O’Neill, B.C., Kriegler, E., Riahi, K., Ebi, K.L., Hallegatte, S., Carter, T.R., Mathur, R., van Vuuren, D.P., 2014. A new scenario framework for climate change research: The concept of shared socioeconomic pathways. Clim. Change 122, 387-400. https://doi.org/10.1007/s10584-013-
Pokhrel, B., 2018. Impact of Land Use Change on Flow and Sediment Yields in the Khokana Outlet of the Bagmati River, Kathmandu, Nepal. Hydrology 5, 22. https://doi.org/10.3390/ hydrology5020022

Randall, D.A., Wood, R.A., Bony, S., Colman, R., Fichefet, T., Fyfe, J., Kattsov, V., Pitman, A., Shukla, J., Srinivasan, J., 2007. Climate models and their evaluation, in: Climate Change 2007: The Physical Science Basis. Contribution of Working Group I to the Fourth Assessment Report of the IPCC (FAR). Cambridge University Press, pp. 589-662.

Riahi, K., van Vuuren, D.P., Kriegler, E., Edmonds, J., O’Neill, B.C., Fujimori, S., Bauer, N., Calvin, K., Dellink, R., Fricko, O., Lutz, W., Popp, A., Cuaresma, J.C., KC, S., Leimbach, M., Jiang, L., Kram, T., Rao, S., Emmerling, J., Ebi, K., Hasegawa, T., Havlik, P., Humpenöder, F., Da Silva, L.A., Smith, S., Stehfest, E., Bosetti, V., Eom, J., Gernaat, D., Masui, T., Rogelj, J., Strefler, J., Drouet, L., Krey, V., Luderer, G., Harmsen, M., Takahashi, K., Baumstark, L., Doelman, J.C., Kainuma, M., Klimont, Z., Marangoni, G., Lotze-Campen, H., Obersteiner, M., Tabeau, A., Tavoni, M., 2017. The Shared Socioeconomic Pathways and their energy, land use, and greenhouse gas emissions implications: An overview. Glob. Environ. Chang. 42, 153-168. https://doi.org/10.1016/j. gloenvcha.2016.05.009

Rimal, B., Zhang, L., Fu, D., Kunwar, R., Zhai, Y., 2017. Monitoring urban growth and the nepal earthquake 2015 for sustainability of Kathmandu Valley, Nepal. Land 6, 42. 
Santhi, C., J.G., A., Williams, J.R., Dugas, W.A., Srinivasan, R., Hauck, L.M., ABSTRACT:, 2001. Validation of the SWAT Model on a Large River Tributing Point and Nonpoint Sources so that the River Watershed in North Central Texas. J. Am. WATER Resour. Assoc. 37, 1169-1188.

Sharma, R.H., Shakya, N.M., 2006. Hydrological changes and its impact on water resources of Bagmati watershed, Nepal. J. Hydrol. 327, 315-322.

Shrestha, M., Acharya, S.C., Shrestha, P.K., 2017. Bias correction of climate models for hydrological modelling-are simple methods still useful? Meteorol. Appl. 24, 531-539.

Shrestha, S., Bhatta, B., Shrestha, M., Shrestha, P.K., 2018. Integrated assessment of the climate and landuse change impact on hydrology and water quality in the Songkhram River Basin, Thailand. Sci. Total Environ. 643, 1610-1622.

Shrestha, S., Shrestha, M., Babel, M.S., 2017. Assessment of climate change impact on water diversion strategies of Melamchi Water Supply Project in Nepal. Theor. Appl. Climatol. 128, 311-323. https://doi. org/10.1007/s00704-015-1713-6

Shrestha, S., Shrestha, M., Babel, M.S., 2016. Modelling the potential impacts of climate change on hydrology and water resources in the Indrawati River Basin, Nepal. Environ. Earth Sci. 75, 280.

Talchabhadel, R., Karki, R., Thapa, B.R., Maharjan, M., Parajuli, B., 2018. Spatio-temporal variability of extreme precipitation in Nepal. Int. J. Climatol. 38, 4296-4313. https://doi.org/10.1002/ joc.5669

Thapa, B.R., Ishidaira, H., Pandey, V.P.,
Shakya, N.M., 2017. A multi-model approach for analyzing water balance dynamics in Kathmandu Valley, Nepal. J. Hydrol. Reg. Stud. 9, 149-162. https:// doi.org/10.1016/j.ejrh.2016.12.080

Thapa, S., Shrestha, A., Lamichhane, S., Adhikari, R., Gautam, D., 2020. Catchmentscale flood hazard mapping and flood vulnerability analysis of residential buildings: The case of Khando River in eastern Nepal. J. Hydrol. Reg. Stud. 30, 100704. https://doi.org/10.1016/j. ejrh.2020.100704

Themeßl, M.J., Gobiet, A., Heinrich, G., 2012. Empirical-statistical downscaling and error correction of regional climate models and its impact on the climate change signal. Clim. Change 112, 449-468.

Venables, W.N., Smith, D.M., 2013. An Introduction to $\mathrm{R}$, Quantitative Geography: The Basics. https://doi. org/10.4135/9781473920446.n12

Venables, W.N., Smith, D.M., Team, R.C., 2018. An introduction to R-Notes on R: A programming environment for data analysis and graphics.

Yang, S., Cui, X., 2019. Building regional sustainable development scenarios with the SSP framework. Sustain. 11, 1-13. https://doi.org/10.3390/su11205712 